\title{
Filter Efficiency of Commercial Face Masks of Particles and Airborne Bacteria
}

\author{
Korebumi MINAKAMI, Tohru OBARA* and \\ Chuhei YAMAUCHI* \\ School of Allied Medical Sciences, Kagoshima University and \\ * Institute of Laboratory Animal Sciences, Faculty of Medicine, \\ Kagoshima University 1208-1, Usuki-cho, Kagoshima \\ 890, Japan.
}

(Received 12 November 1985/Accepted 31 January 1986)

The filter efficiency of seven kinds of commercial face mask for particles and airborne bacteria was tested in the wash room of a laboratory animal facility. The filter efficiency of the masks was 19 to $50 \%$, as measured by the weight of particles with diameters below $10 \mu \mathrm{m}, 22$ to $71 \%$ for particles of the $0.3 \mu \mathrm{m}$ level, 47 to $90 \%$ for the $1 \mu \mathrm{m}$ level, and 90 to $99.6 \%$ for the $5 \mu \mathrm{m}$ level. The filter efficiency for airborne bacteria was 35 to $81 \%$. Among thes even masks tested, glasswool surgery masks, three-sheet synthetic fiber masks with and without charcoal, and 28-sheet gauze masks with glass filter showed generally high efficiency, and single-sheet synthetic fiber masks, 18-sheet of gauze masks and gas masks showed low efficiency.

\section{各種マスクの粉塵及び細菌の捕集効率}

\author{
水上惟文・小原徹* . 山内忠平*
}

鹿児島大学医療技術短期大学部

*鹿児岛大学医学部附属動物実験施没

手術用マスクについては, 素材および構造の違いに より捕集効率に差のあることが報告されている $[3,5$, 8] が, 実験動物施設の作業環境で使用されている各 種マスクの粉塵及び空中細菌の捕集効果についての報 告はほとんよ゙みられない。そこで著者らは，実験動物 施設洗浄室において, 空気中の粉塵重量, 粉塵粒子数, 空中紐菌数に対する各種マスクの捕集効果について検 䒺した。

\section{実験材料および方法}

供武マスクは，グラスウール製手術用マスク（東レ 社製）と日本バイリーン社製の 活性炭をサンドイッチ
状に入れた三枚重ねの合成䋐維布からなるマスク（X642型), 活性炭を入れてない三枚重ねの 合成䋐維布で つくられたマスク（X-302型）及び一枚の合成縺維布 のマスク (打ち抜き型), ガーゼ28枚重站の中にグラス フィルターを入れたガーゼマスク (ホープ社製)，18枚 重ねのガーゼマスク (西武社製) および防毒マスク（コ ウケン社製, サカエ式N-1 型) の 7 種類である。

测定および試料の採取は, 実験動物施設の洗浄室で 污染ケージの㦿教処理作業中に行った。測定方法は, 予め $\mathrm{EO}$ ガスで 2 時間滅菌した内径 $20 \mathrm{~mm}$, 長さ $24 \mathrm{~cm}$ の 程化ビニール管の一端に E Oガス隇菌のマスクを取り つけ, 他端に, 粉塺重量, 精径別の粉鹿粒子数, 細菌 数を捕集・测定するための三本のサンプリングチュー 
ブを取りつけて 行った。粉鹿重量の測定は, ピエゾバ ランス粉塵計 (51-1111, 日本科学工業製) で, 2 分間 $2 \ell$ 空気を吸引し，粒径 $10 \mu \mathrm{m}$ 以下の粉塵重量を測定 した。粉鹿数はパーティクルカウンター $(\mathrm{K} \mathrm{C}-01 \mathrm{~A}$,リ オン社製) とデジタルプリンター（K P - 01, リオン社 製)を用い， 2 分間 1 しの空気を吸引て $0.3 ， 0.5,1,2$, $5 \mu \mathrm{m}$ の粒子径別に測定した。空中細菌はピンホールサ ンプラー（三基科学社製）で每分53lの空気をトリプト ソイ寒天培地に 2 分間吸引して付着させ, $37^{\circ} \mathrm{C}, 72$ 時 間培養して，出現したコロニー 数を計測した。なお， 粉塵重量, 粒子数, 細菌数の測定・捕集は 同封に行っ た。マスク通過前の測定は，マスク通過後の測定終了 後, 取りつけたマスクを外し同様の方法で行った。

マスク通過前と通過後の有意差は, $\mathrm{t}$ 検定で求めた。 捕集効率は，通過前後の 差を通過前の值で割った值と した $[3]$ 。

\section{成 績}

マスク通過前後の, 捕集空気 $1 \mathrm{~m}^{8}$ 当たりの粉鹿重量 と捕集効率は, Table 1 亿示す。各種マスクとも， 、 スク通過後の 粉鹿重量の平均值は，いずれも通過前の 值より少なくなっていたが，防毒マスク以外ではマス クの通過前後の間に有意差を認めなかった。マスクの 捕集効率の最低は，18枚重ねガーゼマスクの $18.7 \%$, 最高は28枚重ねのガーゼマスクの $49.6 \%$ であった。

Table 2 は，マスク通過前後の 粒子径別の粉塵㑬数 とマスクの捕集効率を示す。マスク通過後の粉塵個数 は $0.3 \mu \mathrm{m}$ レベルではグラスウール製マスクのみで, 0.5 $\mu \mathrm{m}$ レベルではグラスウール製マスクと活性炭入り三枚 重ね 合成繊維製 マスクで有意に減少した。2 および 5 $\mu \mathrm{m} レ$ ベルではすべてのマスクの通過後に有意に減少し た。マスクの捕集効率は粒子径が大きくなるにつれて いずれも增加した。各種のマスクを比較すると， 3 群 に分かれ，グラスウール製マスク，三枚重祆の合成䄉 維製マスクでは $0.3 \mu \mathrm{m}$ レベルで60～71\%，1 $1 \mu \mathrm{m}$ レベル で88〜90\%， $5 \mu \mathrm{m}$ レベルで97 99.6\%とあっとあ大き い効率を示した。28枚重ねのガーゼマスクは中間的な

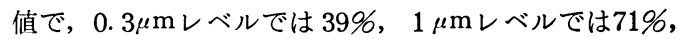
$5 \mu \mathrm{m}$ レベルでは98\%を示した。効率の低いのは一枚の 合成䄉維製マスク，防毒マスク，18枚重ねのガーゼマ スクで， $0.3 \mu \mathrm{m}$ レベルで $21 \sim 28 \% ， 1 \mu \mathrm{m}$ レベルで 47 $62 \%, 5 \mu \mathrm{m}$ レベルでいずれも $90 \%$ 程度の 捕集効率を示 した。素材間では，グラスフィルターを使用したマス クの効率がよく，またフィルター枚数の多い方が高い効 率を示した。

マスク通過前と通過後の空中細菌の捕集効率はTable 3 に示す。マスク通過後の 空中紐菌数は, 一枚の合成 緎維製 マスク以外では有意に減少した。空中細菌の捕 集効率は，グラスウール製マスクと二種類の三枚重ね の合成䄉維製マスクで $80 \%$ 前後，28枚重ねのガーゼマ スクで66\%，防毒マスクと 18枚重㸚のガーゼマスクで 54\%，一枚の合成織維製マスクでは $34 \%$ あった。

なお，洗浄室でのマスク通過前に打ける粉鹿重量あ るいは空中粉塵之粒子径別粉塵個数之の相関 係数は Table 4 亿示すようである。粉塵重量と粒子径別の粉 塵個数との間には $0.3,0.5$ および $1.0 \mu \mathrm{m}$ レベルでは有 意な正の相関 $(\mathrm{p} \leqq 0.01)$ がみとめられたが， 2 及び 5

Table 1. Particle weight before and after mask filtering and filter efficiency

\begin{tabular}{|c|c|c|c|c|c|}
\hline Type of mask & $\begin{array}{l}\text { Numbe } \\
\text { of cases }\end{array}$ & $\begin{array}{l}\text { Particle weight* } \\
\text { before filtering } \\
\left(\mathrm{mg} / \mathrm{m}^{8}\right)\end{array}$ & $\begin{array}{l}\text { Particle weight* } \\
\text { after filtering } \\
\quad\left(\mathrm{mg} / \mathrm{m}^{8}\right)\end{array}$ & Difference & $\begin{array}{l}\text { Filter } \\
\text { efficiency } \\
(\%)\end{array}$ \\
\hline Three-sheet glass fiber surgery mask & 15 & $0.055 \pm 0.007$ & $0.041 \pm 0.006$ & $\mathrm{n} s$ & $35.4 \pm 8.3$ \\
\hline $\begin{array}{l}\text { Three-sheet synthetic fiber mask with } \\
\text { charcoal }\end{array}$ & 15 & $0.077 \pm 0.011$ & $0.057 \pm 0.005$ & $\mathrm{n} s$ & $38.2 \pm 9.6$ \\
\hline $\begin{array}{l}\text { Three-sheet synthetic fiber mask } \\
\text { without charcoal }\end{array}$ & 15 & $0.061 \pm 0.009$ & $0.037 \pm 0.008$ & $\mathrm{n} \mathrm{s}$ & $42.2 \pm 9.0$ \\
\hline Single-sheet synthetic fiber mask & 15 & $0.070 \pm 0.010$ & $0.056 \pm 0.008$ & $\mathrm{n} s$ & $25.0 \pm 6.0$ \\
\hline Gas mask & 15 & $0.083 \pm 0.009$ & $0.050 \pm 0.004$ & $* *$ & $45.2 \pm 8.5$ \\
\hline 28-sheet gauze mask with glass filter & 15 & $0.088 \pm 0.030$ & $0.053 \pm 0.016$ & $\mathrm{n} s$ & $49.6 \pm 8.7$ \\
\hline 18-sheet gauze mask without glass fiber & 15 & $0.092 \pm 0.030$ & $0.085 \pm 0.021$ & $\mathrm{~ns}$ & $18.7 \pm 6.4$ \\
\hline
\end{tabular}

$\mathrm{M} \pm \mathrm{S}$. E., ns: not significant, ${ }^{* *}: \mathrm{p}<0.01, *$ : Weight of particles whose diameters are below $10 \mu \mathrm{m}$. 


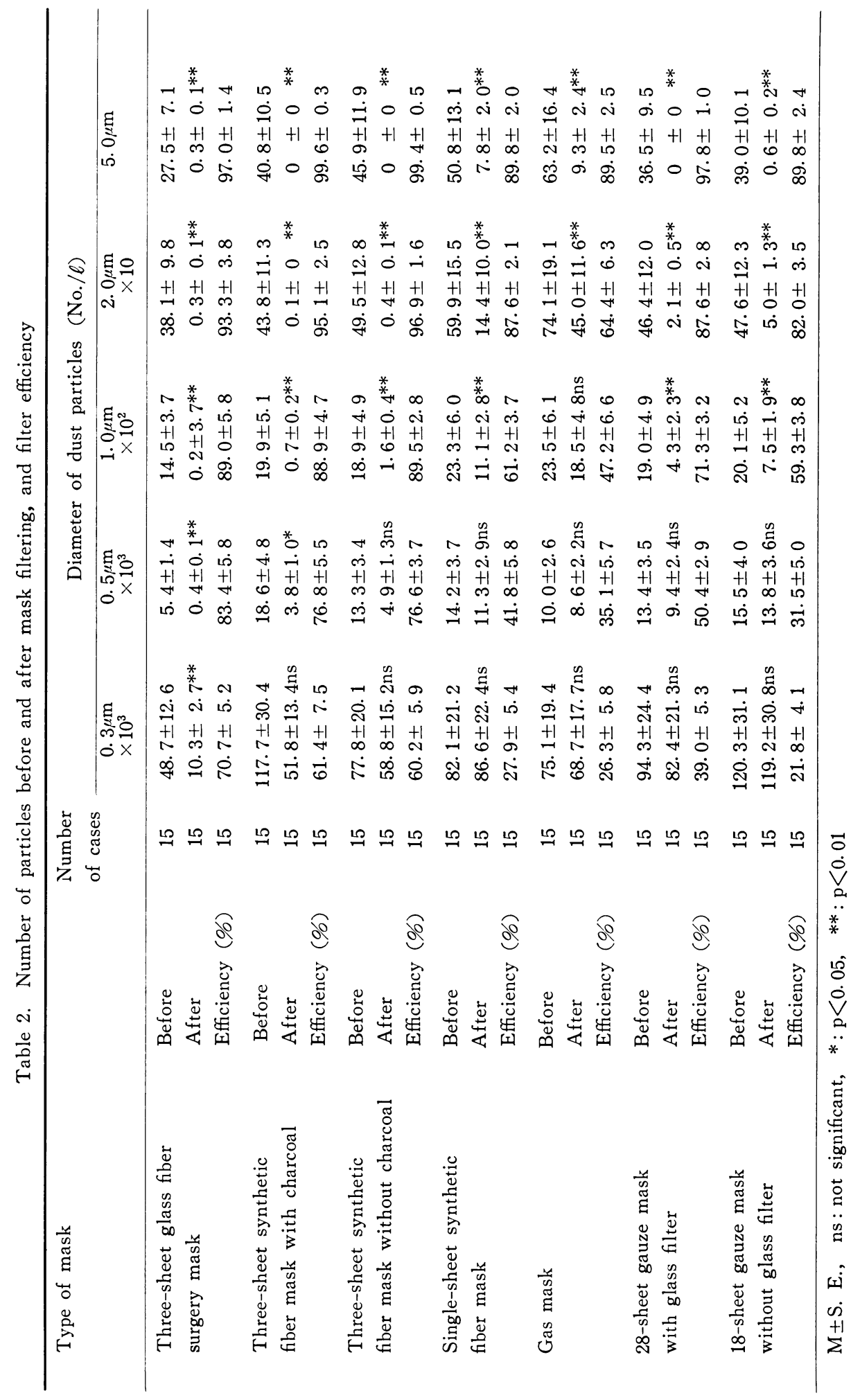


Table 3. Airborne bacteria before and after mask filtering and filter efficiency

\begin{tabular}{|c|c|c|c|c|c|}
\hline Type of mask & $\begin{array}{l}\text { No. of } \\
\text { cases }\end{array}$ & $\begin{array}{l}\text { No. of colonies } \\
\text { before filtering } \\
\text { (Number } / \ell)\end{array}$ & $\begin{array}{l}\text { No. of colonies } \\
\text { after filtering } \\
\text { (Number } / \ell)\end{array}$ & difference & $\begin{array}{l}\text { Filter } \\
\text { efficiency } \\
\quad(\%)\end{array}$ \\
\hline Three-sheet glass fiber surgery mask & 15 & $1.8 \pm 0.3$ & $0.4 \pm 0.1$ & ** & $76.7 \pm 4.8$ \\
\hline $\begin{array}{l}\text { Three-sheet synthetic fiber mask } \\
\text { with charcoal }\end{array}$ & 15 & $3.0 \pm 0.4$ & $0.8 \pm 0.4$ & $* *$ & $80.5 \pm 10.7$ \\
\hline $\begin{array}{l}\text { Three-sheets synthetic fiber mask } \\
\text { without charcoal }\end{array}$ & 15 & $3.3 \pm 0.4$ & $0.6 \pm 0.1$ & $* *$ & $80.5 \pm 9.4$ \\
\hline Single-sheet synthetic fiber mask & 15 & $3.7 \pm 0.4$ & $2.4 \pm 0.5$ & ns & $34.7 \pm 12.7$ \\
\hline Gas mask & 15 & $3.4 \pm 0.5$ & $1.3 \pm 0.3$ & $* *$ & $54.0 \pm 17.5$ \\
\hline 28-sheet gauze mask with glass filter & 15 & $2.9 \pm 0.5$ & $1.2 \pm 0.4$ & $* *$ & $66.6 \pm 17.6$ \\
\hline 18-sheet gauze-mask without glass fiber & 15 & $3.6 \pm 0.6$ & $1.7 \pm 0.5$ & $*$ & $54.5 \pm 12.3$ \\
\hline
\end{tabular}

$\mathrm{M} \pm \mathrm{S} . \mathrm{E} ., \quad \mathrm{ns}:$ not significant, $*: \mathrm{p}<0.05 * *: \mathrm{p}<0.01$

Table 4. Correlations between number of dust particles, dust weight and number of airborne bacteria

\begin{tabular}{|c|c|c|c|c|c|c|}
\hline \multirow{2}{*}{$\begin{array}{l}\text { Particle } \\
\text { size of } \\
\text { dust } \\
\quad(\mu \mathrm{m})\end{array}$} & \multicolumn{3}{|c|}{$\begin{array}{l}\text { Correlation between number of dust } \\
\text { particles and dust weight }\end{array}$} & \multicolumn{3}{|c|}{$\begin{array}{l}\text { Correlation between number of dust } \\
\text { particles and number of airborne bacteria }\end{array}$} \\
\hline & $\begin{array}{l}\text { Number } \\
\text { of cases }\end{array}$ & $\begin{array}{l}\text { Correlation } \\
\text { coefficient }\end{array}$ & $\begin{array}{l}\text { Significant } \\
\text { difference }\end{array}$ & $\begin{array}{l}\text { Number } \\
\text { of cases }\end{array}$ & $\begin{array}{l}\text { Correlation } \\
\text { coefficient }\end{array}$ & $\begin{array}{l}\text { Significant } \\
\text { difference }\end{array}$ \\
\hline 0.3 & 38 & 0.637 & $* *$ & 38 & -0.142 & ns \\
\hline 0.5 & 38 & 0.634 & $* *$ & 38 & -0.183 & ns \\
\hline 1.0 & 38 & 0.541 & $* *$ & 38 & 0.210 & $\mathrm{~ns}$ \\
\hline 2.0 & 38 & 0.297 & ns & 38 & 0.454 & $* *$ \\
\hline 5.0 & 38 & 0.141 & ns & 38 & 0.558 & $* *$ \\
\hline
\end{tabular}

ns : not significant, $* *: \mathrm{p}<0.01$

$\mu \mathrm{m} レ$ ル゙ル゙の相関はみよめられなかった。また, 空中 細菌之粉塵個数との間には $1 \mu \mathrm{m}$ 以下の粉塵では有意な 相関はみとめられなかったが， 2 抢よび $5 \mu \mathrm{m} レ$ レ゙ルて はきわめて有意な正の相関（ $\mathrm{p} \leqq 0.01 ）$ がみとめられ た。表には掲げなかったが, 粉塵重量と空中細菌之の 相関係数は0.065で, 有意な相関はみとめられなかった。

\section{考 察}

歯科材料研磨時に打ける粒径 $5 \mu \mathrm{m}$ 以上の粉塵は重量 にして 70〜95\%が市販のマスクで捕集されたといわれ る [1]。しかし，本実験の動物施設洗浄室に打ける 10 $\mu \mathrm{m}$ 以下の粉應に㧍いては19～50\%の低い捕集効率を示 した。これは使用したマスクの素材扣よび粉塵の種類 の違いによるものであろう。また，本尖験に打いて， 28枚重ねのガーゼマスクの 効率がよいのはグラスフィ
ルターが 内㦲してあるとと，防毒マスクの効率がよい のは吸着剂が入れてあることによるものと考えられる。 Greene ら［6]は，特殊なサンプリングチャンバ中で マスクを着けた場合と着けない場合の測定結果から, 空中細菌に刘するマスクの捕集效率は99.6\%，4 $4 \mathrm{~m}$ 以 下の微粒子数に対する捕集効率は $96.7 \%$ であったと述 べている。また，手術用マスクの材質について細菌の 捕集効率を検討した報告によると, Furuhashi [5]は, グラスウール製マスクで 98. 1 99.4\%，木綿マスクで 43. 1〜93.6\%と述へ，Micik ら［8］はグラスウール製 マスクで 99\%, 合成繊維製マスクで 45〜71\%,ガーゼ マスクで 18〜 57\%，紙製マスクで 32〜33\%，プラスチ ックフォーム製マスクで $14 \%$ 報告している。乙れら の成績と本実験での 紏菌に対する捕集効率を比較する と，グラスウール製では 77\% とやや少ったが，三枚重

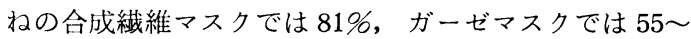


57\%と，本実験の方がやや高い効率を示した。乙の差 は, 粉鹿の質の違いあるいは空気の 吸引方法の違いに よるかもしれない。また，マスクの捕集効率は顔面と の密着度合にあ関係する [7]といわれるので, 使用に 際しては充分な注意が必要であろう。

一方, 細菌やウィルス等の微生物は $5 \mu \mathrm{m}$ 以上の粉塵 に付着して移動しているといわれる [9]が，動物施設 に扔ける粉塵と細菌との関係については, さらに粒子 径別に 分別採取した 粉塵量と空中細菌との 関係につい て検討する必要があろう。

いずれにしても，実験動物施設で使用されている市 販のほとんどのマスクは, $2 \mu \mathrm{m}$ 以上の大型粒子はよく 捕集するので, 空中細菌の吸入防止には有効と思われ る。しかし，実験動物アレルギーの原因となる蛋白抗 原 [4]には極めて小さい微粒子あ含まれるので, マス クを容易に通過することも考えられる。今後とも, 空 調方式, 飼育方法の改良, 防護面, 防應器具の着用な よ゙，総合的な防塵対策が必要と思われる。

\section{要 約}

市販の 7 種類のマスクについて, 動物実験施設洗浄 室における粉塵と空中細菌に対する 捕集効率を検索し た。マスクの捕集効率は, $10 \mu \mathrm{m}$ 以下の粉鹿重量に対し ては平均 19〜50\%，粉塵の粒子径別にみた捕集勃率は 0. $3 \mu \mathrm{m}$ レベルで $22 \sim 71 \%, 1 \mu \mathrm{m}$ レベルで $47 \sim 90 \%, 5$

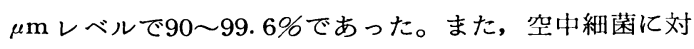
するマスクの捕集効率は 35～81\%であった。試験した マスク間の比較では，グラスウール製手術用，3枚重 ねの合成繊維製 および グラスウール挿入の 28 枚重ねの
ガーゼマスクは一般に高い効率を示した。合成緉維一 枚のマスク，18枚重ねのガーゼマスク扎よびガスマス クは低い効率を示した。

本研究は昭和 60 年度 文部省科学研究費一般研究 $B$, 課題番号 60480486 の一部として尖施したもので，第32 回実験動物学会（橿原）で発表した。

\section{文献}

[1] Brune, D., and Beltesbrekke, H. (1980) Dust in dental laboratories. Part III : Efficiency of ventilation systems and face masks. J. Prosthet. Dent., 44, 211-215.

[2] Comroe, J. H., Jr., Forster, R. E. I., Dubois, A. B., Briscoe, W. A., and Garlsen, E. (1982). “肺 一臨床生理学之肺機能検査法.” 村尾 誠, 本間 威訳, pp 363-370, 医歯薬出版, 東京.

[3] Dineen, P. (1971) Microbial filtration by surgical masks. Surg. Gynecol. Obstet, 133, 812-814.

[4] Edwards, R. G., Beeson, M. F., and Dewdney, J. M. (1983). Laboratory animal allergy: the measurement of airborne urinary allergens and the effects of different environmental condition. Lab. Anim., 17, 235-239.

[5] Furuhashi, M. (1978). A study on the microbial filtration efficiency of surgical face masks with special reference to the non-woven fabric masks. Bull. Tokyo Med. Den. Univ., 25, 7-15.

[7] Ha'eri, G. B., Orth, M'ch., and Wiley, A. M. (1980). The efficany of standard surgical face masks. Clin. Orthop., 148, 160-162.

[8] Micik, R. E., Miller, R. L., and Leong, A. C., (1971). Studies on dental aerobiology: III. Efficacy of surgical masks in protecting dental personnel from airborne bacterial particles. $J$. Dent. Res., 50, 626-630.

[9] 早川一也・都築正和 (1975). 空気調和のための空気清 浄. pp 378,392 , ソフトサイエンス社, 東京. 